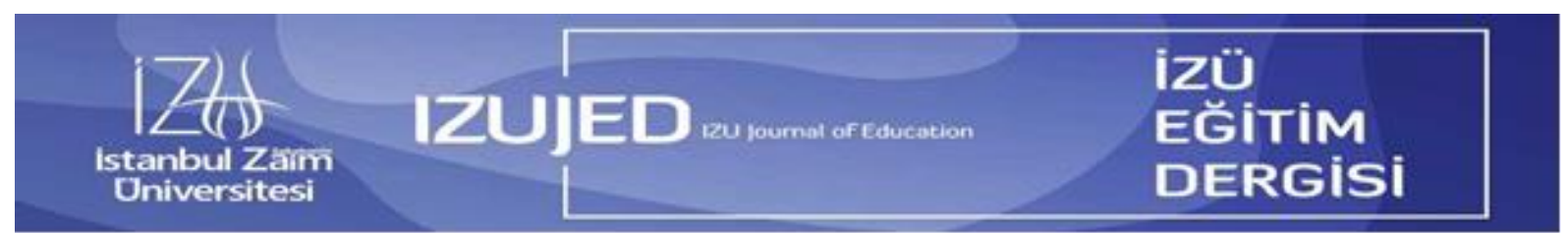

Başvuru: 29 Temmuz 2020

Copyright (c) 2019 İZU

Kabul: 28 Ekim 2020

DOI: 10.46423/izujed.775588

Cilt 2 (2020) Sayı 4 155-173

http://dergipark.gov.tr/izujed

\title{
Okul Yöneticilerinin Etik Liderlik Özellikleri ile Öğretmenlerin Örgütsel Bağlılık Düzeyleri Arasındaki İlişki
}

Metin IŞIKa

Münevver ÇETiN ${ }^{b}$

\begin{abstract}
Öz
Bu araştırmanın amacı, öğretmenlerin algılarına göre okul yöneticilerinin etik liderlik davranışları ile öğretmenlerin örgütsel bağllıkları arasındaki ilişkiyi belirlemektir. Tarama modelinin kullanıldığı araştırmanın çalışma grubunu İstanbul Beylikdüzü ilçesindeki resmi ilköğretim okullarında görevli 1180 öğretmen oluşturmaktadır. Araştırmada "Etik Liderlik Ölçeği" ile "Örgütsel Bağllılı Ölçeği" uygulanmıştır. Veriler, SPSS for Windows 15.0 programı ile çözümlenmiştir. Verilerin analizinde aritmetik ortalama, yüzde, frekans, standart sapma tanımlayıcı istatistikleri ile korelasyon analizi kullanılmıştır. Etik liderlik özellikleri ile öğretmenlerin örgütsel bağlılık düzeyleri arasındaki ilişkinin belirlenmesi için yapılan korelasyon analizi sonucuna göre okul yöneticilerinin etik liderlik davranışları öğretmenlerin örgütsel bağlılık düzeyinin yordayıcısıdır.
\end{abstract}

Anahtar Sözcükler: Etik lider, Örgütsel bağlllık, Okul yöneticisi.

\section{Relationship Between Ethical Leadership of School Principals and Levels of Organizational Commitment of Teachers}

\begin{abstract}
The aim of this research is to determine the relation between ethical leadership behaviours of school principals and teachers' organisal commitment behaviours from the view point of teachers. This research is based on survey-research model. The population constitutes 1180 teachers who were performing in public primary schools in Beylikdüzü District as of 2014 and 2015. In this research ethical leadership scale and organisational commitment scale were used and respectively. SPSS for windows 15.0 program was utilized for data analysis. In the analysis of data frequency, percentage, arithmetic average, standard deviation statistics and the correlation analysis were conducted. According to the correlation analysis results it has been indicated that the level of ethical leadership behaviours of school principals may have a positive impact on the level of organisational commitment behaviours of teachers.
\end{abstract}

Key Words: Ethical leader; Organisational commitment; School administer.

\footnotetext{
a Sorumlu Yazar: Dr., Kırşehir Ahi Evran Üniversitesi a Prof. Dr. Marmara Üniveritesi, Eğitim Fakültesi, Kaman Uygulamalı Bilimler Yüksekokulu, Kırşehir, Türkiye, E mail: isik.metin@ahievran.edu.tr ORCID: 0000-0002-7431-4091 İstanbul, Türkiye E mail: münevvercetin@marmara.edu.tr Atıf: Işık, M. (2020). Okul Yöneticilerinin Etik *Bu çalışma, Dr. Metin Işık'ın Prof. Dr. Münevver Çetin'in danışmanlığında Beykent Üniversitesi Liderlik Liderlik Özellikleri ile Öğretmenlerin Örgütsel Bağlılık Düzeyleri Arasındaki İlişki Sosyal Bilimler Enstitüsünde yaptığı yüksek lisans tezinin bir bölümünden üretilmiştir.

İÜ Eğitim Dergisi, 2(4) 155-173

DOI: 10.46423/izujed.775588
} 


\section{Extended Abstract}

\section{Introduction}

The aim of this research is to examine the relation between ethical leadership behaviours of school principals and teachers' commitment to their organisations. With this reseach, the above-mentioned relation has been revealed. It is crucial to clarify this relation since leadership styles of school principals may enhance the level of teachers' commitment to organisational objects and values.

\section{Method}

The purpose of this research is to investigate the effect of school principals' ethical leadership behaviors and teachers' organizational commitment. The current research is a descriptive study based on the relational model. The research population consists of 1180 teachers working at secondary public schools located in İstanbul Beylikdüzü. Seeing that the research population was accessible, no spesific sample method was used for data selection. After removing out the missing questionnaires, 270 teachers were included in this study. "Ethical Leadership Scale" developed by Y1lmaz (2003) and "Organizational Commitment Scale" developed by Meyer, Allen and Smith (1993) were applied to the participants. Results were given as in the groups of frequency, percentage, arithmetic average and the dispersion of the standard declination on the charts.

In addition, Correlation Analysis is performed in determining the relationship between the ethical leadership of principals and organizational commitment of teachers in the survey. The reliability of the questionnaire was tested using the Alpha Coefficient (Coranbach Alfa). Moreover, in order to be able to determine when the questions are influenced by the alpha coefficient and at what time and in what way; the value of "Alpha if Item Deleted" is calculated. As a result, the reliability of the "Communicative Ethics" factor is $\alpha=0.921$, the reliability value of the "climatic ethics" factor $\alpha=0.939$, the reliability value of the "DecisionBased Ethics" factor $\alpha=0.883$, the "Behavioral Ethics" factor has a reliability value $\alpha=0.950$, the reliability value of the "Emotional Commitment" factor $\alpha=0.652$, reliability value of the "Continuity" factor $\alpha=0,697$, the reliability value of the "Normative Commitment" factor was found to be $\alpha=0.746$.

\section{Findings and Discussion}

According to the opinions of participatory school principals and teachers, it appears that there is a meaningful but weak connection between ethical leadership behaviours and teachers' organisational commitment in decision-making within subdimensions of ethical emotional commitment, cummunicational ethics-attandance commitment and; climatic ethics- attendance commitment. There seems to be meaningful relation at medium level among communicational ethics, climatic ethics, behavioral ethics, emotional and normative commitment and ethics and normative commitment in decison-making. It is seen that there is meaningful relation with teachers' marital status and their decision about their administrators in sub-dimension of ethics, so married teachers think of their administrators' leadership as more ethical in decison-making for ethical dimension. 
It appears that there is meaningful relation between teachers' emotional commitment which is subdimension of organizational commitment and their professional seniority. Moreover, It is apparent that teachers having 6-10 year experience have lower commitment level when compared to others. It seems that the relation between the seniority of principals and ethical leadership in climatic ethic sub-dimension is meaningful and teachers having 1 year or less experience have higher level of commitment than other teachers. It appears that the relation is meaningful between ethical leadership and subject in decision-making sub-dimension and also within this dimension Mathematics, English and Informatics teachers have more average than other teachers. Thus, subject variable affects the evaluations of teachers in deciding administrators' ethical behaviours in ethical sub-dimension (Mathematics, English and Informatics teachers consider administrators as more ethical in this dimension of leadership).

The results of this research have revealed that there is positive and meaningful relation between the ethical leadership of school administrators and teachers' commitment at various sub-dimensions and also ethical leradership characteristics have a a positive impact upon teachers' commitment. Teachers' impression of their school principals as being honest and reliable individuals could have a noticeable impact on their organisational commitment.

The results of this research indicate that school principals demonstarting ethical leadership characteristics are crucial in ensuring teachers' organisational commitment and also school principals could behave more ethically in administrative issues and provide the necessary support to their teachers so as to increase their level of organisational commitment.

\section{Giriş}

Son yıllarda küreselleşme ve bilgi teknolojilerindeki gelişmeler ve değişen eğitim anlayışları nedeniyle sosyal hayatta önemli değişimler yaşanmakta ve bu hızlı değişimde en zor rolü liderler üstlenmektedir. Okulların yaşanan değişime uyum sağlamasında yöneticiler önemli rol üstlenirken, toplumun devamlılığı için bireylerin birbirlerine ve yöneticilere güvenmesi gerekir. Ancak yaşanan değişimler ile okul yöneticileri bazı etik sorunlar yaşamaktadır. Okul yöneticisinin inandığı davranışların oluşmasında etik değerler ve ilkeler sağlam bir temel oluşturur (Aydın, 2002: 38). Eğitim yönetimi, okulların başarılı yöneticiler tarafından yönetilmesini ve donanımlı bireyler yetiştirmesini amaçlamaktadır. Okul ortamları sürekli yenilenmeyi ve gelişmeye ihtiyaç duymaktadır. Toplumun okuldan beklentilerini karşılamak için öğrencilerin iyi yetişmesine yönelik düzenlemeler yapılmalıdır. Bu açıdan yaşanan yeni durumlara yönelik eğitim yöneticilerinin yaklaşımları (Karagöz, 2006: 1) hem okul ortamının hem de kendilerinin gelişmelerine katkı sağlayacaktır. Okulun lideri, olaylar karşısında bilim ve akıl odaklı davranarak bilimsel gelişmeleri takip eden ve okuyan bir lider olmalıdır (Gümüşeli, 2001: 543). İnsanın ilgi ve yetenekleri doğrultusunda eğitimdeki hedeflerin gerçekleştirilmesine uygun yetiştirilmesi beklenmektedir (Fidan, 1997: 4). Okulların toplumun geleceğindeki önemi sebebiyle eğitim yöneticilerinin okul yönetimlerindeki liderlik tarzı, çalışanların kuruma bakış açısını etkilemektedir. Okul yöneticisi bir eğitim lideri olarak eğitimi geliştirmek gibi kurum üstü toplumsal hedef ve sorumluluklar taşımaktadır. Bu yüzden okul yöneticilerinin göstereceği liderlik türü olarak etik liderlik, diğer liderlik türlerinden farklı olarak liderin karar ve davranışlarında etiksel sorumluluk gerektirir. Karslı (2004)'ya göre liderin yönetimsel karar ve davranışlarında adil, dürüst, eşit davranan, herkese saygılı davranan, hoşgörülü, sorumluluk sahibi, şeffaf olmak gibi etik ilkelere uymalıdır. Okulda bu 
ilkelerin içselleştirilmesi liderin ve öğretmenlerin etik yaklaşımlarına bağlıdır. Etik lider olarak okul yöneticisi, öğretmenlerin kurumlarına bağlılığını etkileyen etmenlerin en önemlilerinden birisidir.

Okulda, yöneticilerin etik liderlik rolüne uygun olarak etik davranması ve çalışanlara yol göstermesi beklenmektedir (Arslantaş ve Dursun, 2008). Okul ortamında başarı için yöneticilerin etik liderlik özellikleri öğretmenlerin örgütsel bağlılıklarına ve okulun başarısına olumlu katkı sağlayacağı beklenmektedir. Eğitim örgütlerinin etkililiğini sürdürebilmesi ve okullarda beklenen gelişmenin sağlanmasında da yöneticilerin etik liderlik özellikleri taşıması, yönettikleri kurumlarda örgütsel bağlılık seviyesinin yüksek olması, kurumda etik yapı ve bağlılık ortamı oluşturmaları bir ihtiyaç olarak görülebilir. Okul yöneticilerinin liderlik tarzı, öğretmenlerin okullarına bağlılıklarına yansımaktadır. Bu araştırmada okul yöneticilerinin etik liderlik özellikleri ile öğretmenlerin örgütsel bağlılıkları arasındaki ilişkinin incelenmesi hedeflemektedir.

\section{Etik Liderlik}

Lider, örgütün amaçları doğrultusunda gelişmesinde önemli rolü olan birey (Şişman ve Turan, 2001: 43); liderlik güven, sevgi, tutarlılık ve sabır isteyen bir süreçtir (Ferik, 2001: 78). Modern yaklaşımlara göre liderlik, yöneticinin takımda çalışan kişiler bütününü oluşturmasıdır (Yavuz, 2006). Liderliğin etik-ahlaki boyutuna önem veren yaklaşımlar, yeni bir liderlik anlayışı olarak etik liderin etik bir kültür oluşturma sorumluluğu olduğunu göstermektedir (Turhan, 2007: 6). Etik liderlik teorileri, etik liderliğin yapılması gereken kurallara göre dayanması ve liderliğin gelişmesi için etik davranışları kapsaması esasına dayanmaktadır (Değirmenci, 2003). Eğitimin amaçlarının belirlenmesi ve gerçekleştirilmesinde, çağımızın okul yöneticilerinin yönetimsel işlerde etik ilkelerle tutarlı davranış göstermeleri gerekir. Çağı yakalamak için okul yöneticisi dürüst, adil ve ahlaklı bir tutum içinde yani etik lider olmalıdır (Gümüşeli, 2001: 531).

Etik liderlik, kişisel davranışlarında ve ilişkilerinde normatif açıdan doğru davranan, karşılıklı iletişim ve etkili düşünme yöntemi ile arttırmayı hedefler (Brown vd., 2005: 120). Etik liderlik üçe ayrılır: Hizmete yönelik liderlik, otantik liderlik ve ilke merkezli liderlik. Hizmete yönelik lider, örgüt çalışanlarına ve topluma hizmet etmeyi kendi çıkarlarının üzerinde tutarak bunu etik bir sorumluluk ve değer olarak görür. Otantik liderler güvenilirlik ve ustalıklarıyla ayırt edilirler (Turhan, 2007: 37). İlke merkezli liderin kişilik özellikleri izleyenleri etkiler ve belirli ilkelere uygun davranması beklenmektedir. Liderin etkili kişilik özellikleri göstermesi izleyenlere güven verir ve ilke ve kuralların kurum kültürüne yerleştirilmesi etkili olur (Turhan, 2007: 38). Üç liderlikte de iyi okul yöneticisi, olumlu bir okul kültürü oluşturmak ve hedeflere ulaşmak için yöneticilik ve liderlik davranışlarını birleştirebilmelidir (Pehlivan, 1993: 157). Etik liderlikten beklenen davranış eylemlerin hepsinde etik değerlere bağlı bir şekilde ifade edilmesidir (Yılmaz, 2006: 34). Okul yöneticisinin değişimi başlatma ve yönetme alanında önemli rolleri vardır (Şişman, 2002: 64). Bu açıdan etik liderlik özellikleri taşıyan okul yöneticilerinden değişimi daha kolay yönetmeleri beklenmektedir. Yıldırım (2010), Kurşun (2011), Kaya (2014) ile Tabancalı ve Çakıroğlu (2017)'nun araştırmasında kullandığı boyutlar olarak İletişimsel etik, iklimsel etik, karar vermede etik, davranışsal etik (Y1lmaz, 2006: 88-89) bu çalışmada da kullanılmıştır. Okul yöneticisinin etik liderlik becerileri doğru kararlar verebilmesi için gereklidir. Çünkü değerler sistemi haklı-haksız, iyi-kötü ve doğru-yanlıştan oluşan etik lider örgütünü geliştirir. Bu açıdan eğitim yöneticilerinin etik değerlere sahip olmaları liderlik rolünü kazanabilmelerinde önemli rol oynar (Aydın, 2002: 156). Böylece eğitim kurumlarındaki 
mesleki etik ilkelere uyum sağlanacaktır. Okul yöneticisi, eğitimin herkese eşit sunulmasında örnek gösterilen lider olmalıdır (Küçükkaraduman, 2006: 35). Örgütte görevlerin çalışanlara adil olarak paylaştırılması zorunludur (Pehlivan, 1993: 39). Öğrencilerin model alacakları kişiler olan okul yöneticilerinin etik liderlik rollerini yerine getirmeleri önem taşımaktadır (Turhan, 2007: 54). Okul yöneticisi, okul toplumuna ve çevresine liderlik yaparak okulu geliştirme ve öğrenci başarısını arttırma sorumluluğunu (Doğan, 2006: 30-31) taşımaktadır.

\section{Örgütsel Bağlılık}

Bağlılık, bir kurum, düşünce ve kişiye karşı aidiyet ve yerine getirilmesi gereken yükümlülüktür. Örgütler üyelerinin örgütsel hedeflere ulaşmasında önemi olan bağlılık düzeylerini artırmak isterler (Bülbül, 2007: 10). Örgütsel bağllığın üç göstergesi bulunmaktadır: İzleyenlerin örgüt amaçlarını kabul etmesi, bunun için gayret etmesi, örgütte devamlılık için istek (Balay, 2000: 18) hissetmesidir. Bir çalışanın örgüte olan bağl1lığı duygusal, devam ve değer (normatif) bağlılık şeklinde ifadesi kabul edilmiştir. Duygusal bağlllık, örgüte yönelik hissedilen duygusallığa işaret eder. Devam bağlılı̆̆1 ise izleyenlerin iş terkinin oluşturacağ maddi yüke dayanan örgütsel bağlılık durumudur. Normatif bağlılık, çalışanın örgütte devam etmeye ahlaki bir sorumluluk ile karar vermesini ifade eder (Ölçüm, 2004: 91-92). Bireyler bir örgüte, bazı istek ve ihtiyaçlar ile gelir ve yeteneklerini kullanabilecekleri, ihtiyaçlarını karşılayabilecekleri bir ortam beklerler (Eser, 2007). Beklentilerinin karşılanması örgütsel bağlılık düzeyini önemli ölçüde etkileyecektir. Örgütsel bağlılık üç grupta sınıflandırılmaktadır.

Tablo 1. Örgütsel Bağlılı̆ğın Sınıflandırılması

\begin{tabular}{|c|c|c|c|}
\hline I- & Tutumsal Bağlılık & II- Davranışsal Bağlılık & III- Çoklu Bağlılık \\
\hline$\bullet$ & Kanter'in Yaklaşımı & - $\quad$ Becker'in Yaklaşımı & - $\quad$ Reichers Yaklaşımı \\
\hline$\bullet$ & Etzioni'nin Yaklaşımı & - Salancik'in Yaklaşımı & \\
\hline & $\begin{array}{l}\text { R'Reilly ve Chatman'in } \\
\text { Yaklaşımı }\end{array}$ & & \\
\hline & $\begin{array}{l}\text { Penley ve Gould'un } \\
\text { Yaklaşımı }\end{array}$ & & \\
\hline
\end{tabular}

Kaynak: İnce, M. ve Gül, H. Yönetimde Yeni Bir Paradigma: Örgütsel Bă̆lllık, 2005, s.26.

\section{Tutumsal bağlılık}

Bireylerin insanlara, nesnelere ya da olaylara yönelik sürekli eğilimleri yani belirli bir davranışa yönlendiren tutumlarını göstermektedir (Ceylan, 1998: 72). Araştırmacılara göre tutumsal bağlılık farklı şekillerde ortaya çkabilmektedir (Bülbül, 2007: 10). Örgütsel bağlılık, kişinin çalıştığı kuruma karşı hissettikleridir. Kanter'e göre, devam bağlılığı, çalışanların kendini örgütün devamlılığına adamasını; gruba ve grup içi ilişkiler ile kenetlenme bağlllı̆̆; kontrol bağlılığ1 ise üyelerin liderin kurallarını devam ettirmesidir (Gül, 2002: 42). Etzioni (1975), örgütün üyeler üzerindeki gücünün, üyenin örgüt algısından kaynaklandığını ileri sürer (Çakır, 2007: 18). Ahlak bağlamında örgüt amaçları, değer ve normlarının benimsenmesine bağlı olarak örgüte duyulan olumlu eğilime moral bağlılık denir. Bu bağlllıkta birey, duygusal açıdan bağlllık hissetmemesine rağmen üye kalmaya mecbur edilir (Balay, 2000: 17-18). Etzioni (1975)'ye göre olumlu üst yoğunluklu katılma bağl1lı; olumsuz ve alt düzey katılım ise yabancilaşmadır (Çakır, 2007: 18-19). QReilly ve Chatman (1986)'a göre, kişinin örgütüne duygusal bağlılığı olarak örgütsel bağlılık üç boyuttan oluşur: Uyum bağlılığında diş ödüllere 
ulaşmayı amaçlar. Özdeşleşme, yakın ilişkiler kurma isteğine dayanır. İçselleştirme ise kişisel ve sosyal değerlerin uyumuna bağlıdır (Balay, 2000: 22-23). Penley ve Gould'a göre, ahlaki olan bağlılık modelinin (Etzioni: 1975) çıkarcı ve yabancılaştırıcı özelliklerine rağmen uygun olduğunu bu yüzden alanyazında ilgi görmediğini belirtmektedirler (Gül, 2002: 44). Tutumsal bağlılık, Allen ve Meyer (1990)'e göre izleyenlerin örgüt ile ilişkisini ifade eden ve bireyin, örgütte kalmaya devamlılık göstermesi olan psikolojik bir durumdur ve üç boyutu bulunmaktadır:

- Duygusal bağllikk,

- Devam bağlilığ1 ve

- Normatif bağlilik.

Duygusal bağlılık, bireylerin örgütle özdeşleşmesini; devam bağlılığı (rasyonel bağlılık), ayrılmanın maliyeti, kıdem, kariyer gerekçeleri ile üyeliğinin sürdürülmesini ve normatif (ahlaki) boyutta izleyen görev olarak örgüte bağl1lık gösterir ve örgüte bağlllığı da bir doğru olarak düşünür (Gül, 2000: 45-46).

\section{Davranışsal bağlılık}

Bireylerin deneyimleri ve örgüte uyumları oranında bağlanma süreci kapsamında değerlendirilebilir. Örgütsel bağllıkta süreklilik, örgütten ayrılmamaya isteklilik, devamlılık gösterme davranışlarını içerir (Çakır, 2007: 12-13).

\section{Çoklu bağlılık}

Çoklu bağlılık, farklı düzeylerde bağlılık türlerinin örgüt içinde oluşması diğer iki bağlılıktan bağımsız ele alınmaktadır (Balay, 2000: 24-26). Örgütsel bağlılık, bireysel özellikler, kişilik, iş ve rol özellikleri ile tecrübe, yapısal özellikler (Çetin, 2004: 99) gibi çok sayıda faktörden etkilenmektedir. Ayrıca örgütsel bağlılık ile kişisel faktörler arasında çok etkili bağlar bulunmaktadır. Kişisel faktörler örgütsel değerlerin ve hedeflerin benimsenerek bireyin uzun dönem örgütte kalmasını sağlamaktadır. İzleyenlerin, üst seviye bağlılık göstermeleri güçlü katılımcı değerler gösterdikleri sonucuna ulaştırır.

İnsanın özgürleştirilmesi süreci olan eğitim ile öğrenci birey olma yetisi kazanır, ahlaki bir yapı oluşturur. Ancak bu ahlaki yapı içerisinde öğrenenin kendisine ve etrafındaki insanlara karşı sorumluluk duyması gerekir (Hesapçığlu, 2004: 2). Başarılı okul yönetimi için ahlaki inançlar zorunlu yeterliliklerle birlikte etik ölçütler ve yönelimler bulunmalıdır. Etik ilkelere bağlı her okul yöneticisi okulunda eğitimin gelişimine katkı sağlar (Çelik, 2000: 92). Okul yöneticileri öğretmenlerin bağlılı̆̆ını arttırarak güç ve yetki alanlarını genişletebilirler. Yöneticilerine bağlı öğretmenler de daha verimli ve yaratıcı olurlar (Yardibi, 1991: 1-2). Örgütsel bağlılık, örgüt ile çalışan arasındaki dengeyi ve uyumu gösteren ölçüttür (Çetin, Basım ve Aydoğan, 2011). Bu yüzden okul yöneticisinin etik lider davranışlar sergilemesi, öğrencilerin de okulda belirlenen etik ilke ve kuralları benimsemelerini ve hayatlarında etik ilkelere uygun davranmalarını sağlayacaktır. Örgütsel bağlılığın amaç ve sonuçlarıyla, genelde liderliğin özelde etik liderliğin amaç ve sonuçları ortak noktada birleşmektedir. Örgütsel bağlılık, çalışanların benimsediği örgüt hedefleri, değer ve amaçları için gönüllü olarak emek göstermesi ve devamını istemesidir (Dilek, 2005: 144). Farklı çalışmalarda örgütsel bağlllık ile görev ve ilişki yönelimli liderlik arasında etkili ilişki vardır. Liderin çalışanların ihtiyaçlarına olan hassasiyeti ile örgütsel bağlılıkla ilişki bulunmaktadır. Blau 
(1985) ile Williams ve Hazer (1986) örgütsel bağlılık ve liderlik arasındaki ilişkide çalışanlara önem veren liderlik uygulamalarının örgütsel bağlılığı etkilediğini vurgular (Çırpan, 1999: 65). Okulların niteliğinin ve çalışanların bağlılık düzeyinin arttırılması ile okul yöneticilerinin etik liderliği birbiriyle bağlantılıdır. Okullarda yöneticilerin etik davranması, çalışanların bağlılıklarını ve yöneticilerine desteklerini kolaylaştıracaktır (Küçükkaraduman, 2006: 35). Etik lider olarak okul yöneticisi, örgütsel bağl1lı̆ı temin etmek ve devam ettirecek uygulama ve programlar geliştirmek zorundadır (Kılıç, 2006: 160).

Her örgütte gösterilen liderlik tarzları ve yönetim, örgüt içi değer ve ortak hedeflere bağlılığı olumlu etkilemektedir. Çünkü liderden memnun olma, örgütsel bağlllık açısından belirleyicidir (İnce ve Gül, 2005: 72). Öğretmenlerin okul yöneticilerini etik lider olarak algılamaları ve örgütsel bağlılık hissetmeleri için, yöneticilerin dürüst ve adil olması ve davranışlarıyla göstermesi gerekir. Yöneticiler öğretmenlerle, ailelerle, öğrencilerle ilişkilerinde dürüst ve sorumlu davranmalıdır. Etik liderlik, öğretmen ve diğer okul unsurlarının örgütsel bağlılık düzeylerini bilinmesinin alana önemli katkı sağlayacağı düşünülmektedir. Bu çalışmada, okul yöneticilerinin etik liderlik davranışlarını öğretmenlerin örgütsel bağlllık düzeyine etkisi incelenmektedir.

\section{Yöntem}

Bu bölümde araştırmanın modeli, evren ve örneklem, veri toplama araçları ile verilerin toplanması ve analizi yer almaktadır.

\section{Araştırmanın Modeli}

Bu çalışma, okul yöneticilerinin etik liderlik özellikleri ile öğretmenlerin örgütsel bağlılıkları arasındaki ilişkiyi incelemek için nicel araştırma yöntemlerinden ilişkisel tarama modeli kullanılmıştır. Tarama modelleri, mevcut ve geçmiş yaşanan durumlar olduğu biçimde betimleyen (Karasar, 2009: 77) yaklaşımlardır. Farklı değişkenler bağlamında karşılaştırma yapılması yönüyle çalışma ilişkisel bir araştırmadır (Erkuş, 2005). Araştırma kapsamında yöneticilerin liderlik davranışları "İletişimsel Etik", “İklimsel Etik", "Karar Vermede Etik" ve "Davranışsal Etik" boyutları; öğretmenlerin örgütsel bağlılık düzeyleri ise "Duygusal Bağlılık", “Devam Bağlılığı" ve "Normatif Bağlılık” boyutları altında incelenmiştir (Yılmaz, 2006).

\section{Evren ve Örneklem}

Eğitim kurumlarında çalışan öğretmen ve yöneticiler araştırmanın hedef kitlesini oluşturmaktadır. İstanbul ili Beylikdüzü ilçesindeki farklı eğitim kurumlarında bulunan yönetici ve öğretmenlerden örneklem oluşturulmuştur. Tesadüfi olarak belirlenen 270 öğretmen ve yöneticiye uygulanan ölçeklerden 262 kullanılabilir formda ölçek verisi elde edilmiştir. Geriye kalan toplam 262 ölçek değerlendirmeye alınarak örneklemi oluşturmuştur.

\section{Verilerin Toplanması ve Çözümlenmesi}

Araştırmada veri toplama aracı olarak kullanılan ölçek formunda, etik liderlik ve örgütsel bağlılık olarak iki ölçek bulunmaktadır. Formlar, araştırmacı tarafından öğretmen ve yöneticilere elden dağıtılarak uygulanmıştır. Araştırmada "Etik Liderlik Ölçeği" 44 madde (Yılmaz, 2005) ve “Örgütsel Bağlılık Ölçeği" (Meyer ve Allen, 1997) 18 maddeden 
oluşmaktadır. Etik liderlik ölçeği (Yılmaz, 2005) dört boyuttan oluşur: İletişimsel etik, iklimsel etik, karar vermede etik, davranışsal etik. Okul yöneticisinin göstereceği etik liderlik davranışlarını, okul yöneticisinin kendi bireysel davranışlarında, okul iklimi oluşturmada, karar verme ve iletişim sürecindeki etik davranışları dört boyutta göstermelidir (Yılmaz, 2006: 88-89). Meyer ve Allen (1997) tarafından geliştirilen "Örgütsel Bağlllık Ölçeği" (Organizational Commitment Questionere: OCQ), örgütsel bağlılı̆̆ı; duygusal bağlılık, devam bağlılığı ve normatif bağlllık olmak üzere üç temel bileşene ayırarak ölçmeyi amaçlamıştır (Baysal ve Paksoy, 1999: 8). Ölçek güvenilirliği için Alfa Katsayısı (Croanbach Alfa)'dan yararlanılmıştır. Analizler için 262 katılımcıya ait veriler kullanılmıştır. Ankette yer alan ölçek sorularının, alfa katsayısına etki yön ve derecesini belirleyebilmek için; "Değişken Silindiği Takdirde Ölçeğin Alfa Katsayısı" değeri hesaplanmıştır. Bunun sonucunda "İletişimsel Etik" faktörünün güvenilirlik değeri $\alpha=0,921$, "İklimsel Etik" faktörünün güvenilirlik değeri $\alpha=0,939$, "Karar Vermede Etik" faktörünün güvenilirlik değeri $\alpha=0,883$, “Davranışsal Etik" faktörünün güvenilirlik değeri $\alpha=0,950$, "Duygusal Bağlılık" faktörünün güvenilirlik değeri $\alpha=0,652$, “Devam Bağlılığı" faktörünün güvenilirlik değeri $\alpha=0,697$, "Normatif Bağlılık" faktörünün güvenilirlik değeri $\alpha=0,746$ olarak bulunmuştur.

Çalışmada analiz yöntemlerinin tespitinde yapılan Kolmogorov-Smirnov Z testi, örneklemin dağılım normal dağılım arasındaki farksızlığı gösterin bir testtir. Örneklem dağılımı ile normal dağılım arasındaki uygunluk, örneklemin genel olarak evreni temsil ettiğine ve ölçeğin geçerliliğini desteklediğine kabul edilir.

Tablo 2. Kolmogorov-Smirnov Z Analizi Sonuçları

\begin{tabular}{|c|c|c|c|}
\hline \multicolumn{2}{|c|}{ Faktör } & Etik & Bağlılık \\
\hline \multicolumn{2}{|c|}{$\mathrm{N}$} & 260 & 260 \\
\hline \multirow{2}{*}{$\begin{array}{c}\text { Normal } \\
\text { Parametreler }\end{array}$} & Ortalama & 4,09 & 3,29 \\
\hline & Std. Sapma & ,75 & ,63 \\
\hline \multirow{3}{*}{$\begin{array}{l}\text { En Aşırı } \\
\text { Farlılıklar }\end{array}$} & Mutlak &, 11 & ,09 \\
\hline & Pozitif & ,11 & ,09 \\
\hline & Negatif &,- 08 &,- 03 \\
\hline \multicolumn{2}{|c|}{ Kolmogorov-Smirnov Z } & 1,88 & 1,47 \\
\hline \multicolumn{2}{|c|}{ Anlamlılık } & ,10 & ,12 \\
\hline
\end{tabular}

Analiz sonuçları anlamlılık değeri p > 0,05'den olduğu için örneklemin dağılımının normal dağılım gösterdiği varsayılarak regresyon analizi ve varyans analizi ile değişkenler arasındaki ilişkiler belirlenmiştir.

\section{Bulgular}

Bulgular bölümünde araştırmanın amacına yönelik analiz edilen veriler değerlendirilmiştir. Araştırma kapsamında yöneticilerin liderlik davranışları "İletişimsel Etik", "İklimsel Etik", "Karar Vermede Etik" ve "Davranışsal Etik" boyutları; öğretmenlerin örgütsel bağlılık düzeyleri ise "Duygusal Bağlılık", "Devam Bağlılığı" ve "Normatif Bağlılık" boyutları altında incelenmiştir.

\section{Demografik özelliklere ilişkin bulgular}


Katılımcların frekans ve yüzde tanımlayıcı istatistikleri kullanılarak demografik özelliklerine göre dağılım incelenmiştir.

Tablo 3. Katılımcıların cinsiyetlerine göre dağılımı

\begin{tabular}{cccccc}
\hline & & $f$ & \% & Geçerli \% & Toplamsal \% \\
\hline \multirow{3}{*}{ Geçer } & Erkek & 106 & 40,5 & 40,9 & 40,9 \\
\cline { 2 - 6 } & Kadın & 153 & 58,4 & 59,1 & 100,0 \\
\cline { 2 - 6 } & Toplam & 259 & 98,9 & 100,0 & \\
\hline Kayıp & Veri & 3 & 1,1 & & \\
\hline \multicolumn{7}{c}{} & Toplam & 262 & 100,0 & & \\
\hline
\end{tabular}

Cinsiyete göre katılımcıların \% 41'inin erkek, \% 58'inin kadın olduğu; medeni durumlarına göre \% 80'inin evli, \% 20'sinin bekâr; yaşlarına göre \% 23'ünün yaşının 30 ve altı, \% 46'sının 31-40 arası, \% 23'ünün 41-50 arası, \% 8'inin ise yaşının 51 ve üzeri olduğu anlaşılmaktadır. Ayrıca mesleki kıdemlerine göre dağılımları katılımcıların \% 14'ünün 1-5 yıl arası, \% 31'nin 6-10 yıl arası, \% 33'ünün 11-20 yıl arası, \% 23'ünün 21 yıl ve üzeri mesleki kıdem sahibi olduğu görülmektedir.

Tablo 4. Katılımcıların mesleki kıdemlerine göre dağılımı

\begin{tabular}{|c|c|c|c|c|c|}
\hline & & $\bar{f}$ & $\%$ & Geçerli \% & Toplamsal \% \\
\hline \multirow{5}{*}{ Geçer } & $\begin{array}{c}1-5 \mathrm{y} 11 \\
\text { arasi }\end{array}$ & 35 & 13,4 & 13,6 & 13,6 \\
\hline & $\begin{array}{l}6-10 \text { yil } \\
\text { aras1 }\end{array}$ & 80 & 30,5 & 31,0 & 44,6 \\
\hline & $\begin{array}{c}11-20 \text { y1l } \\
\text { aras1 }\end{array}$ & 85 & 32,4 & 32,9 & 77,5 \\
\hline & $\begin{array}{c}21 \text { yil ve } \\
\text { üzeri }\end{array}$ & 58 & 22,1 & 22,5 & 100,0 \\
\hline & Toplam & 258 & 98,5 & 100,0 & \\
\hline Kayıp & Veri & 4 & 1,5 & & \\
\hline \multicolumn{2}{|c|}{ Toplam } & 262 & 100,0 & & \\
\hline
\end{tabular}

Okul kıdemlerine göre dağılımları Tablo 5'te özetlenmiştir. Tablodaki değerlerden katılımcların \% 21'inin 1 yıl ve daha az, \% 58'inin 2-5 yıl arası, \% 16'sının 6-10 yıl arası, \% 4'ünün 11 yıl ve üzeri okul kıdemine sahip olduğu anlaşılmaktadır.

Tablo 5. Okul Kıdemlerine Göre Dağılımı

\begin{tabular}{llllll}
\hline & & \% & Geçerli \% & Toplamsal \% \\
\hline \multirow{6}{*}{ Geçer } & $\begin{array}{l}\text { 1 y1l ve } \\
\text { daha az } \\
2-5 \text { y1l }\end{array}$ & 54 & 20,6 & 21,2 & 21,2 \\
& $\begin{array}{l}\text { arası } \\
6-10 \text { yıl } \\
\text { arasi }\end{array}$ & 41 & 56,9 & 58,4 & 79,6 \\
& $\begin{array}{l}11 \text { y1l ve } \\
\text { üzeri }\end{array}$ & 11 & 15,6 & 16,1 & 95,7 \\
& Toplam & 255 & 4,2 & 4,3 & 100,0 \\
\hline Kayip & Veri & 7 & 97,3 & 100,0 & \\
\hline
\end{tabular}


Toplam 262 100,0

Şekil 1'de Branşlarına göre dağılımları özetlenmiştir. Şekildeki değerlerden katılımcıların \% 50 'sinin sınıf öğretmeni, \% 6'sının matematik, \% 7'sinin sosyal bilgiler, \% 4'ünün fen ve teknoloji, \% 9'unun İngilizce, \% 7'sinin Türkçe, \% 3'ünün bilişim, \% 15'inin beden eğitimi branşlarında olduğu anlaşılmaktadır.
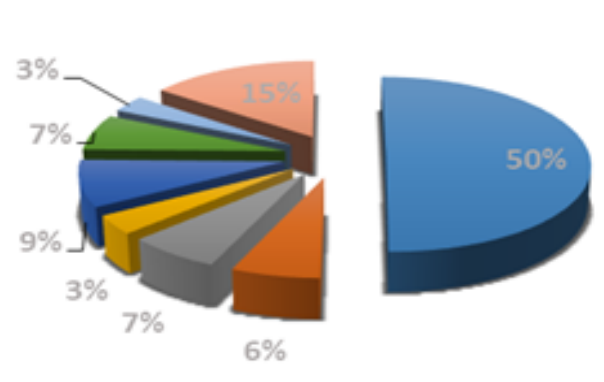

=Sınıf Ögrretmeni

matematik

- Sosyal Bilgiler

a Fen ve Teknoloji

a Ingilizce

E Türkçe

= Bilişim

믈 Beden Eğitimi

\section{Şekil 1. Katılımcıların branşlarına göre dağılımı}

Görevlerine göre dağılımları Şekil 2'te özetlenmiştir. Şekildeki değerlerden katılımcıların \% 94'ünün öğretmen, \% 5'inin müdür yardımcısı, 1 kişinin ise müdür olduğu anlaşılmaktadır.

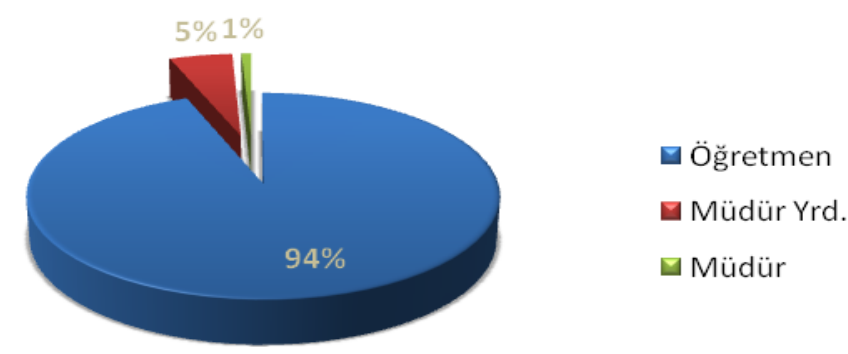

Şekil 2. Katılımcıların branşlarına göre dağılımı

\section{Okul yöneticilerinin etik liderlik özelliklerine ilişkin bulgular}

Bu bölümde okul yöneticilerinin etik liderlik özellikleri aritmetik ortalama ve standart sapma tanımlayıcı istatistikleri kullanılarak incelenmiş ve analiz sonuçları Tablo 6' da sunulmuştur. Tablodaki veriler yöneticilerin "İletişimsel Etik" faktöründen Xort = 4,17, "İklimsel Etik" faktöründen Xort = 3,96, "Karar Vermede Etik" faktöründen Xort = 4,02, "Davranışsal Etik" faktöründen Xort $=4,21$ puan aldıkları göstermektedir. 
Ölçekte en yüksek puanın 5 olduğu ve "4" değerinin katılıyorum ifadesine karşılık geldiği değerlendirildiğinde okul yöneticilerinin genellikle etik liderlik davranışları sergiledikleri söylenebilir.

Tablo 6. Okul Yöneticilerinin Etik Liderlik Davranışları

\begin{tabular}{lccccc}
\hline & N & Minimum & Maksimum & Ortalama & $\begin{array}{c}\text { Standart } \\
\text { Sapma }\end{array}$ \\
\hline İletişimsel Etik & 260 & 1,00 & 5,00 & 4,17 &, 70 \\
\hline İklimsel Etik & 260 & 1,00 & 5,00 & 3,96 &, 86 \\
\hline Karar Vermede Etik & 260 & 1,00 & 5,00 & 4,02 &, 88 \\
\hline Davranışsal Etik & 260 & 1,00 & 5,00 & 4,21 &, 81 \\
\hline
\end{tabular}

\section{Öğretmenlerin örgütsel bağlılık düzeylerine ilişsin bulgular}

$\mathrm{Bu}$ bölümde aritmetik ortalama ve standart sapma tanımlayıcı istatistikleri kullanılarak öğretmenlerin örgütsel bağlılık düzeyleri incelenmiş ve analiz sonuçlarına göre öğretmenlerin "Duygusal Bağlllık" faktöründen Xort = 3,38, "Devam Bağl1lığı" faktöründen Xort = 3,12, "Normatif Bağlılık" faktöründen Xort = 3,38 puan aldıklarını görülmektedir. Ölçekten alınabilecek maksimum puanın 5 olduğu ve “3" değerinin kararsızım ifadesine karşılık geldiği değerlendirildiğinde öğretmenlerin örgütsel bağlılıklarının orta düzeyde olduğu söylenebilir. Ayrıca standart sapma değerlerinin 0,68 ile 0,90 arasında değişmesi öğretmenlerin örgütsel bağlılık düzeylerinin tutarlı olduğu ve öğretmen bazında farklılık göstermediğini ortaya koymaktadır.

Tablo 7. Okul Yöneticilerinin Etik Liderlik Davranışları

\begin{tabular}{lccccc}
\hline & $\mathbf{N}$ & Minimum & Maksimum & Ortalama & Standart Sapma \\
\hline $\begin{array}{l}\text { Duygusal } \\
\text { Bağlılık }\end{array}$ & 260 & 1,00 & 5,00 & 3,38 &, 68 \\
\hline $\begin{array}{l}\text { Devam } \\
\text { Bağlılığ }\end{array}$ & 260 & 1,00 & 5,00 & 3,12 &, 90 \\
\hline $\begin{array}{l}\text { Normatif } \\
\text { Bağlılık }\end{array}$ & 260 & 1,00 & 5,00 & 3,38 &, 89 \\
\hline
\end{tabular}

Bu bölümde etik liderlik davranışları ile öğretmenlerin örgütsel bağlılıkları arasındaki ilişki korelasyon ve regresyon analizleri yardımıyla incelenmiştir. Tablo 8'deki verilerden Karar vermede etik, davranışsal etik ile devam bağlılığı arasındaki ilişkinin istatistiksel olarak anlamlı olmadığını ortaya koymaktadır. Buna göre söz konusu değişkenler arasında herhangi bir ilişki bulunmamaktadır.

Tablo 8. Okul Yöneticilerinin Etik Liderlik Davranışları ile Öğretmenlerin Örgütsel Bağlılık Düzeyleri Arasındaki İlişki

\begin{tabular}{lcccc}
\hline & $\begin{array}{c}\text { Duygusal } \\
\text { Bağlılık }\end{array}$ & $\begin{array}{c}\text { Devam } \\
\text { Bağlılığı }\end{array}$ & Normatif Bağlılık \\
\hline İletişimsel Etik & $\begin{array}{c}\text { Pearson } \\
\text { Korelasyonu }\end{array}$ &, $22\left(^{* *}\right)$ &, $15\left(^{*}\right)$ &, $33\left(^{* *}\right)$ \\
\hline & Anlamlılı &, 00 &, 01 &, 00 \\
\hline $\mathrm{N}$ & 259 & 259 & 259 \\
\hline İklimsel Etik & Pearson &, $27\left(^{* *}\right)$ &, $13\left(^{*}\right)$ &, $35\left(^{* *}\right)$ \\
\hline
\end{tabular}




\begin{tabular}{lcccc}
\hline & Korelasyonu & & & \\
\hline & Anlamllık &, 00 &, 03 &, 00 \\
\hline $\begin{array}{l}\text { Karar Vermede } \\
\text { Etik }\end{array}$ & $\mathrm{N}$ & 25 & 259 & 259 \\
\hline & $\begin{array}{c}\text { Pearson } \\
\text { Korelasyonu }\end{array}$ &, $14\left(^{*}\right)$ &, 07 &, $26\left(^{* *}\right)$ \\
\hline & Anlamll1ık &, 01 &, 25 &, 00 \\
\hline Davranişsal Etik & $\mathrm{N}$ & 259 & 259 & 259 \\
\hline & $\begin{array}{c}\text { Pearson } \\
\text { Korelasyonu }\end{array}$ &, $23\left(^{* *}\right)$ &, 10 &, $35\left(^{* *}\right)$ \\
\hline & Anlamll1k &, 00 &, 10 &, 00 \\
\hline & $\mathrm{N}$ & 259 & 259 & 259 \\
\hline
\end{tabular}

Karar vermede etik ile duygusal bağlılık, iletişimsel etik ile devam bağlılığı ve iklimsel etik ile devam bağlılığı arasında ise anlamlı fakat zayıf bir ilişki bulunmaktadır. Bunlar dışındaki etik liderlik ve bağlılık boyutları arasındaki ilişkiler ise istatistiksel olarak orta düzeyde anlamlı ilişkilerdir.

Okul yöneticilerinin etik liderlik davranışları ile öğretmenlerin örgütsel bağlılıkları üzerindeki genel etkisi ayrıca regresyon analizi yardımıyla incelenmiş ve analiz sonuçları Tablo 9'da verilmiştir. Tablonun anlamlılık sütunundaki değerden $(\mathrm{p}=0,00)$ söz konusu değişkenler arasındaki ilişkinin istatistiksel olarak anlamlı olduğu anlaşılmaktadır.

Tablo 91. Okul Yöneticilerinin Etik Liderlik Davranışları ile Öğretmenlerin Örgütsel Bağlılık Düzeyleri Arasındaki İlişki

\begin{tabular}{clccccc}
\hline \multirow{2}{*}{ Model } & & $\begin{array}{c}\text { Kareler } \\
\text { Toplamı }\end{array}$ & df & $\begin{array}{c}\text { Ortalama } \\
\text { Kare }\end{array}$ & F & Anlamlılık \\
\hline \multirow{3}{*}{1} & Regresyon & 9,69 & 1 & 9,69 & 26,14 &, $00(\mathrm{a})$ \\
\cline { 2 - 8 } & Fark & 95,32 & 257 &, 37 & & \\
\cline { 2 - 7 } & Toplam & 105,01 & 258 & & & \\
\hline
\end{tabular}

Etik liderlik davranışlarının öğretmenlerin örgütsel bağlılık düzeyine yordama açıklama derecesini gösteren Model Özeti Tablo 10'da verilmiştir. Tablodaki değerlerden $(R 2=0,092)$ etik liderliğin örgütsel bağlılığ $1 \% 9$ oranında etkilediği sonucuna ulaşılmıştır.

Tablo 10. Model Özeti

\begin{tabular}{ccccc}
\hline Model & $\mathbf{R}$ & R Kare & Düz. R Kare & Std. Hata \\
\hline 1 &, $30(a)$ &, 09 &, 08 &, 60 \\
\hline
\end{tabular}

a Bağımsız Değişken: (Sabit), Etik

Etik liderlik davranışları ile öğretmenlerin duygusal bağlılıkları üzerindeki etkisi regresyon analizi yardımıyla incelenmiş ve analiz sonuçları Tablo $11^{\prime}$ de verilmiştir. Tablonun anlamlılık sütunundaki değerden $(p=0,00)$ söz konusu değişkenler arasındaki ilişkinin istatistiksel olarak anlamlı olduğu anlaşılmaktadır.

Tablo 11. Okul Yöneticilerinin Etik Liderlik Davranışları ile Öğretmenlerin Duygusal Bağlılık Düzeyleri Arasındaki İlişki

\begin{tabular}{llllll}
\hline Model & Kareler Toplamı & df & Ortalama Kare & F & Anlamlılı \\
\hline
\end{tabular}




\begin{tabular}{ccccccc}
\hline \multirow{3}{*}{1} & Regresyon & 9,84 & 4 & 2,46 & 5,58 &, $00(\mathrm{a})$ \\
& Fark & 111,85 & 254 &, 44 & \\
\cline { 2 - 7 } & Toplam & 121,69 & 258 & & \\
\hline
\end{tabular}

a Bağımsız Değişken: (Sabit), Davranışsal Etik, Karar Vermede Etik, İletişimsel Etik, İklimsel Etik

b Bağımlı Değişken: Duygusal Bağlılık

Etik liderlik davranışlarının öğretmenlerin örgütsel bağlılık düzeyine etki derecesini gösteren Model Özeti Tablo 12 'de verilmiştir. Tablodaki değerlerden $\left(R^{2}=0,081\right)$ etik liderliğin duygusal bağlılığı \% 8 oranında etkilediği sonucuna ulaşılmıştır.

Tablo 12. Model Özeti

\begin{tabular}{ccccc}
\hline+ & $\mathrm{R}$ & $\mathrm{R}$ Kare & Düz. R Kare & Std. Hata \\
\hline 1 &, $28(\mathrm{a})$ &, 08 &, 06 &, 66 \\
\hline \multicolumn{4}{c}{ a Bağımsız Değişken: (Sabit), Davranışsal Etik, Karar Vermede } \\
Etik, İletişimsel Etik, İklimsel Etik
\end{tabular}

Etik liderlik davranışları ile öğretmenlerin devam bağlılıkları üzerindeki etkisi regresyon analizi yardımıyla incelenmiş ve analiz sonuçları Tablo 11'de verilmiştir. Tablonun anlamlllık sütunundaki değerden $(p=0,60)$ söz konusu değişkenler arasındaki ilişkinin istatistiksel olarak anlamlı olmadığı anlaşılmaktadır.

\section{Sonuç, Tartışma ve Öneriler}

Okul yöneticilerinin etik liderlik davranışları ve öğretmenlerin örgütsel bağlılık düzeylerine ilişkin katılımcı görüşlerine göre, okul yöneticilerinin etik liderlik davranışlarını sergiledikleri ve öğretmenlerin ise okullarına orta düzeyde bağlı oldukları belirtilmektedir. Öğretmenlerin, okullarındaki yöneticilerin uygulamalarını etik ya da etik dışı yönünde değerlendirdikleri ve önemsedikleri görülmektedir. Öğretmenlerin örgütsel bağlılıkları, motivasyonları ve çalışma verimliliklerini etkileyen önemli etkenlerden biri de liderin davranışları olarak yordanabilir. Benzer sonuçlara farklı çalışmalarda da ulaşılmıştır. Örgütsel bağlılık için çalışanların örgüt içinde eşit ve adil olarak çalışmalarına olan inançları (Yazıcıoğlu ve Topaloğlu, 2009) gerekli görülmekte ve örgütsel bağlılığı yüksek insanların iş tatmini yüksek olduğundan daha verimli (Bilgen, 2014) çalışabilmektedirler. Sonuç olarak örgütsel bağlılığı yüksek öğretmenlerin iş tatmini yüksek olacağından devam bağlılığının da yüksek olması beklenmektedir. Yapılan çalışmada öğretmenlerin örgütsel bağlılık düzeyleri ile okul yöneticilerinin etik liderlik davranışlarında tutarlılıkları arasında olumlu yönde etkileşim bulunmaktadır.

Öğretmenlerin örgütsel bağlılıklarına okul yöneticilerinin etik liderlik davranışları genellikle anlamlı etkisinin olduğu ve öğretmenlerin örgütsel bağlılığını \% 9 oranında etkilediği sonucuna ulaşılmıştır. Bu sonuç Fındıkçı'nın (2015) araştırmasında etik liderlik ile örgütsel bağlılık arasında benzerlik olduğu, etik liderlik anlayışı olan bir örgütte örgütsel bağlılık düzeyinin artması beklentisi ile uyumlu görülmektedir. Çalışma ortamlarında anlayışın etik olması ve korunması için yönetici etik standartları ve rol model uygulamaları sergilemeleridir (Aydın 2001: 40). Öğretmenlerin örgütsel adalet algıları da örgütsel bağlılık düzeylerine yansıyarak bağlılı̆̆ın artma veya azalmasına sebep olduğu (Şahin ve Kavas, 
2016: 140) etik liderlik davranışlarının örgütsel bağl1lı̆̆ doğrudan etkilediği yönünde yorumlanabilir.

Karar vermede etik boyutunda okul yöneticilerinin davranışsal etik davranışları ile öğretmenlerin devam bağl1lı̆̆ı arasında anlamlı bir ilişki olmadığı görülmüştür. Örgütsel bağlılığın her alt boyutu önemli olmasına rağmen öğretmenlerin, okul yöneticilerinin karar vermede gösterdikleri etik davranışları, onların devam bağl1lığ1 boyutunda örgütsel bağlılıklarını etkilemediği görülmektedir. Okullarda diğer örgütlerden farklı olarak anlık gelişen durumlarda okul yöneticilerinin karar almasının olağan görülmesi ile yorumlanabilir. Oysa çalışanların yüksek örgütsel bağl1lıkları, güçlü bir örgüt kültürünün olduğunu ve çalışanların da çalışma verimini arttıracak yönde örgüte bağlılık hissettikleri ve örgüte olumlu yansıdığı düşünülmektedir (Güçel, 2013).

Karar vermede okul yöneticilerin etik davranışları ile öğretmenlerin duygusal bağlılıkları; okul yöneticilerinin iletişimsel etik davranışları ile öğretmenlerin devam bağlılıkları ve okul yöneticilerinin iklimsel etik davranışları ile öğretmenlerin devam bağlılıkları arasında anlamlı fakat zayıf bir ilişki olduğu sonucuna ulaşılmıştır. Bunlar dışındaki alt boyutlarda ise okul yöneticilerinin etik liderlik davranışları ve öğretmenlerin örgütsel bağlılık boyutları arasındaki ilişkiler ise istatistiksel olarak anlamlı orta düzeyde olarak yorumlanabilir. Benzer bulgulara Karahan (2008)'ın araştırmasında, Liderlik ile örgütsel bağllilı arasındaki ilişkilerin anlamlı olduğu; çalışanların örgütsel bağlılığını liderlik tarzının olumlu yönde etkilediği (Karahan, 2008); çalışanlar ve ihtiyaçlarına hassas olunan etik kültürün örgüte bağlılığı kuvvetlendirdiği (Cullen, 2003); çalışanların örgüte bağlılıkları ile etik liderlik arasında ilişkinin olumlu olduğu (Muller, 2000) ileri sürülmüştür (Akt. Altun, 2013: 48).

Eğitim yöneticilerinin etik liderlik davranışları, öğretmen duygusal bağlılıklarına istatistiksel açıdan etkisi genel anlamlıdır. Yöneticilerin etik liderliği öğretmenlerin duygusal bağlılığını $\% 8$ oranında etkilediği sonucuna ulaşılmıştır. Ancak etik liderlik uygulamaları ile öğretmen devam bağlılığına istatistiksel açıdan genel etkisi anlamlı olmadığı yönünde sonuca ulaşılmıştır. Diğer bir ifade ile okul yöneticilerinin etik liderliği öğretmenlerin devam bağlılığından bağımsız olup, öğretmenlerin devam bağlılıklarını etkilememektedir. Alanyazında ise alınan ücret, prim, terfi gibi kazanımların, örgüte sağladıkları düşünülen katkıya denk olmadığı yönündeki algıları duygusal bir kırılma ve tutum ve davranışlarının bağlılık, motivasyon ve yeterlilik duygularına zarar vererek tükenmişliğe sebep olmaktadır (Schepman ve Zarate, 2008; Akt: Yeniçeri, Demirel ve Seçkin 2009). Okul yöneticilerinin etik liderlik davranışları, öğretmenlerin ücret, prim, terfi gibi kazanımlarını etkilemediğinden öğretmenlerin devam bağlılıklarına yansımadığına yordanabilir.

Bu çalışmada okul yöneticilerinin etik liderlik davranışları ile öğretmenlerin okula normatif bağlılıklarında genel etkisinin istatistiksel açıdan anlamlı bulunmuştur. Etik liderlik davranışları, öğretmen normatif bağlılıklarını \% 14 oranında etkilemektedir. Herrbach ve arkadaşları (2007) yaptıkları çalışmada örgütsel etik değerleri benimseyenler ile örgütsel bağlılık arasında doğrudan pozitif bir ilişki tespit etmişlerdir. Öğretmenlerin daha fazla sorumluluk aldığı okullarda başarı artacağından, okul yöneticilerinin etik liderlik davranışları öğretmenlerin normatif bağlılı̆̆ına dolayısıyla okul başarısına olumlu yansıyacaktır. Yönetici davranışlarının öğretmenlerin örgütsel bağlığı üzerindeki etkileri araştırmasına göre, öğretmenlerin okullarıyla aidiyetlerindeki farklılaşmanı \% 40 oranında 
yönetici davranışına bağlı memnuniyet ile \% 20 okul yönetimine öğretmenlerin katılımları ile ilişkili olduğu bulgusuna ulaşılmıştır (Karahan, 2008: 148-149).

Yapılan araştırmalar (Karahan, 2008; Herrbach ve arkadaşları, 2007; Cullen, 2003; Muller, 2000; Tamer, 2017) etik liderliğin sahip olduğu ilkelerin örgütsel bağlılığın ortaya çıkmasını kolaylaştıracağını desteklemektedir. Bu açıdan etik liderlerin örgüt içerisinde her birey üzerinde ilgisini hissettirmesi önemli bir husustur. Değer gören her birey örgüte karş1 bağlllık hissederek örgütün amaçlarına ulaşabilmesi için üst seviyede performans gösterecektir. Nitekim bu çalışmada da okul yöneticilerinin etik liderliğin farklı boyutlarındaki davranışlarının öğretmenlerin örgütsel bağlılık düzeylerini etkilediğini göstermektedir.

$\mathrm{Bu}$ çalışma genel olarak değerlendirildiğinde okul yöneticilerinin etik liderlik davranışları ile öğretmenlerin örgütsel bağlılıkları arasındaki ilişkinin karar vermede etik, davranışsal etik ile devam bağlılığı arasındaki ilişkinin istatistiksel olarak anlamlı olmadığı ancak karar vermede etik ile duygusal bağlılık, iletişimsel etik ile devam bağl1lığ devam bağlılığı arasında anlamlı fakat zayıf bir ilişki bulunduğu anlaşılmaktadır. İletişimsel etik, iklimsel etik ve davranışsal etik ile duygusal bağlllık ve normatif bağlılık arasında; karar vermede etik ile normatif bağlılık arasında istatistiksel olarak orta düzeyde anlamlı olduğu görülmektedir.

Araştırma sonuçları değerlendirildiğinde araştırmacı ve uygulayıcılara şu öneriler sunulmuştur:

Örgütsel bağl1lık, örgütsel hedeflere ulaşmada oldukça önemlidir. Bütün örgütlerde olduğu gibi eğitim örgütlerinde de çalışanların bağlılık düzeylerini artırmak gerekmektedir.

Örgütsel bağlılı̆̆ 1 arttırmak için mesleki gelişimin teşvik edilmesi, kurs ve seminerlerin cazip hale getirilmesi, öğretmenlerim eğitim ihtiyaçlarının belirlenerek eğitim verilmesi gerekmektedir.

Okul müdürlerinin etik liderlik davranışlarının öğretmenlerin örgütsel bağlılı̆̆ını etkilediği araştırma ile ortaya konulmuştur. Okul yöneticilerinin etik liderlik özelliklerinin geliştirilmesi için belirli zaman aralıklarında hizmet içi eğitim ve seminerler düzenlenmelidir.

Araştırmanın Türkiye genelinde daha fazla sayıda öğretmen ve yönetici ile yapılması okul yöneticilerinin etik liderlik davranışlarının belirlenmesinde ve öğretmenlerin örgütsel bağlılık düzeylerindeki ilişki hakkında evren temsil edilecektir.

Farklı ilçeleri veya illeri kapsayan bir çalışma bölgesel farklılıkların okul yöneticilerinin etik liderlik davranışları ile öğretmenlerin örgütsel bağlılık düzeyleri arasındaki ilişkinin incelenmesi açısından yararlı olacaktır.

\section{KAYNAKÇA}

Allen, N. J., \& Meyer, J. P. (1990). The measurement and antecedents of affective, continuance and normative commitment to the organization. Journal Of Occupational And Organizational Psychology, 63(1), 1-18.

Altun, Y. (2013). Çalışanların Örgütsel Bağlllık Düzeylerine Yöneticilerinin Etik Liderlik Davranışlarının Etkisi. Yayımlanmış Yüksek Lisans Tezi, Bahçeşehir Üniversitesi. 
Arslantaş, C. ve Dursun, M. (2008). Etik liderlik davranışının yöneticiye duyulan güven ve psikolojik güçlendirme üzerindeki etkisinde etkileşim adaletinin dolaylı rolü. Anadolu Üniversitesi Sosyal Bilimler Dergisi, 8(1) 111-128.

Aydın, İ. P. (2002). Yönetsel Mesleki ve Örgütsel Etik. Pegem Akademi, Ankara.

Aydın, İ. P. (2003). Eğitim ve Öğretimde Etik. Pegem Akademi, Ankara.

Balay, R. (2000). Yönetici ve Öğretmenlerde Örgütsel Bă̆lılık. Pegem Akademi, Ankara.

Balcı, A. (1993). Etkili Okul. Pegem Akademi, Ankara.

Baysal, A. C. ve Paksoy, M. (1999). Mesleğe ve Örgüte Bağlılı̆̆ın Çok Yönlü İncelenmesinde Meyer-Allen Modeli. İstanbul Üniversitesi İşletme Fakültesi Dergisi, 28(1), 7-15.

Başaran, İ. E. (1991). Örgütsel Davranış: İnsanın Üretim Gücü. Gül Yayınevi, Ankara.

Bilgen, A. (2014). Çalışanların Etik Liderlik ve Etik İklim Algılamalarının Örgütsel Bă̆hllklarına Etkisi: Özel ve Kamu Sektöründe Karşılaştırmalı Bir Uygulama. Yüksek Lisans Tezi, Bahçeşehir Üniversitesi Sosyal Bilimler Enstitüsü, İstanbul.

Brown, M. E., Trevino, L. K. \& Harrıson, D. A. (2005). Ethical Leadership: A Social Learning Perspective for Construct Development and Testing. Organizational Behavior and Human Decision Processes, Vol.97, pp.117- 134.

Bülbül, M. (2007). Örgütsel Bağlllık ve Kamu Kuruluşlarına Yönelik Araştırma. Yayınlanmış Yüksek Lisans Tezi, Kahramanmaraş Sütçü İmam Üniversitesi, Kahramanmaraş.

Ceylan, A. (1998). Örgütsel Davranışın Bireysel Boyutu. Gebze Yüksek Teknoloji Enstitüsü, İzmit.

Cullen, J.B., Parboteeah, K.P. ve Victor, B. (2003), “The Effects Of Ethical Climates On Organizational Commitment: A Two-Study Analysis", Journal Of Business Ethics, Vol.46, pp. 127-141.

Çakır, A. (2007). İlköğretim Okullarında Görev Yapan Öğretmenlerin Örgütsel Bağhllık Düzeyleri ve Okul Kültürü Algıları Arasındaki İlişkinin İncelenmesi. Yayımlanmış Yüksek Lisans Tezi, Yeditepe Üniversitesi Sosyal Bilimler Enstitüsü, İstanbul.

Çırpan, H. (1999). Örgütsel Öğrenme İklimi ve Örgüte Bağlllık İlişkisi. İstanbul Üniversitesi. (Yayımlanmış Doktora Tezi), İstanbul Üniversitesi, İstanbul.

Çelik, V. (2000). Eğitimsel Liderlik. Pegem Akademi, Ankara.

Çelik, Keleş, H. N. (2006). İş tatmininin örgütsel bağlılık üzerindeki etkisine ilişkin ilaç üretim ve dağıtım firmalarında yapılan bir araştırma. Selçuk Üniversitesi Sosyal Bilimler Enstitüsü Dergisi, Konya.

Çetin, Ö. M. (2004). Örgüt Kültürü ve Örgütsel Bağlılık. Ankara, Nobel Yayınc1lık.

Çetin, F., Basım., H. N. ve Aydoğan, O. (2011). Örgütsel Bağlılığın Tükenmişlik ile İlişkisi: Öğretmenler Üzerine Bir Araştırma, Selçuk Üniversitesi Sosyal Bilimler Enstitüsü Dergisi, s. $61-70$.

Değirmenci, T. (2003). Eğitim Yöneticisinin Liderlik Davranışı, Kocaeli, Haziran 2003. 
Dilek, H. (2005). Liderlik Tarzlarının ve Adalet Algısının; Örgütsel Bağhllık, İş Tatmini ve Örgütsel Vataşdaşlık Davranışı Üzerine Etkilerine Yönelik Bir Araştırma. Yayımlanmış Doktora Tezi, Gebze Y.T.E.

Doğan, V. (2006). İlköğretim Okulu Müdürlerinin Toplumsal Liderlik Yeterliklerinin Belirlenmesi. Yayınlanmış Yüksek Lisans Tezi, Yıldız Teknik Üniversitesi, İstanbul.

Erbaş, M. (2008). “Etik Lider”. http://www.muhammeterbas.com.tr/index. (14.08.2008)

Erkuş, A. (2005). Bilimsel Araştırma Sarmalı. Seçkin Yayınları, 1. Baskı, 199.

Eser, G., (2007). Etik İklim ve Yöneticiye Güvenin Örgüte Bağlılığa Etkisi, Yayınlanmış Yüksek Lisans Tezi, Marmara Üniversitesi, İstanbul.

Etzioni, A. (1975). Comparative analysis of complex organizations, rev. Simon and Schuster.

Fındıkçı, Y. M. (2015). Etik Liderliğin Yöneticiye Güvene ve Örgütsel Bağlılığa Etkisi Üzerine Ampirik Bir Çalışma, Yayımlanmış Yüksek Lisans Tezi, Yeditepe Üniversitesi Sosyal Bilimler Enstitüsü.

Fidan, N. (1997). Eğitim Psikolojisi: Okulda Öğrenme ve Öğretme. Ankara.

Ferik, F. (2001). İşletmelerdeki Liderlik Tarzlarının Çalışanların İş Tatminleri Üzerindeki Etkisi, Bankacılık ve Finans Dergisi, Yıl 4, Sayı 19.

Güçel, C. (2013). “Örgütsel Bağlılığın Örgütsel Vatandaşlık Davranışına Etkisi Örgütsel Adaletin Aracılık Rolü: İmalat İşletmelerine Yönelik Bir Araştırma", İşletme Araştırmaları Dergisi, 5(2), 173-190.

Gül, H. (2002). Örgütsel Bağlllık Yaklaşımlarının Mukayesesi ve Değerlendirmesi. Ege Akademik Bakış Dergisi, 2(1), 37-56.

Gümüşeli, A. İ. (2001). Çağdaş Okul Müdürünün Liderlik Alanları. Kuram ve Uygulamada Ĕ̆itim Yönetimi Dergisi, 7(4), 531-548.

Hesapçıŏlu, M. (2004). "Eğitim Nedir?". Cumhuriyet, 30 Nisan 2004.

İnce, M. ve Gül, H. (2005). Yönetimde Yeni Bir Paradigma: Örgütsel Bă̆gllık. Konya: Çizgi Yayıncilik.

Karagöz, B. K. (2006). Okul Yöneticilerinin Yönetim Süreçleri Açısından Karşılaştıkları Problemler. Yayımlanmış Yüksek Lisans Tezi, Trakya Üniversitesi, Edirne.

Karahan, A. (2008). Hastanelerde liderlik ve örgütsel bağlılık arasındaki ilişkinin incelenmesi. Sosyal Bilimler Dergisi, 10(1), 145-162.

Karasar, N. (2009). Bilimsel araştırma yöntemleri. Ankara: Nobel Yayınları.

Karslı, M. (2004). Yönetsel Etkililik. Pegem Akademi, Ankara.

Kılıç, G. (2006). Eğitim Kurumlarında Liderlik Tarzları ve Örgüt Kültürünün Performans Üzerindeki Etkisi. Yayımlanmış Yüksek Lisans Tezi, Erciyes Üniversitesi.

Kırel, Ç. (2000). Örgütlerde Etik Davranışlar, Yönetimi ve Bir Uygulama Çalışması. Anadolu Üniversitesi Yayınları, No:1211, İ.İ.B.F. Yayınları No:168, Eskişehir. 
Kurşun, A. T. (2011). Okulların Kurumsal İmajının Okul Yöneticilerinin Etik Liderlik Özellikleri ve Bazı Değişkenler Açısından İncelenmesi. Yayımlanmamış Yüksek Lisans Tezi, Selçuk üniversitesi Eğitim Bilimleri Enstitüsü, Eğitim Bilimleri Anabilim Dalı, Konya.

Küçükkaraduman, E., (2006). İlköğretim Okul Müdürlerinin Etik Davranışlarının İncelenmesi. Yayımlanmış Yüksek Lisans Tezi, Gazi Üniversitesi, Ankara.

Meyer, J. P. and Allen, N. J., (1991), “A Three Component Conceptualization of Organizational Commitment", Human Resources Management Review, Vol.1, pp. 61-89.

Meyer, J. and Allen, N. (1997). Commitment in The Workplace, Thousand Oaks SAGE Publications, CA.

O’Reilly, C. ve Chatman, J. (1986). “Organizational Commitment and Psychological Attachment: The Effects of Compliance, Identification and Internalization on Prosocial Behavior", Journal of Applied Psychology, Cilt 71, Sayı 3, ss.492-499.

Ölçüm, Ç. (2004). Örgüt Kültürü ve Örgütsel Bağlllık. Ankara: Nobel Yayınları.

Pehlivan, İ. (1993). Yönetimde Stres Kaynakları. Yayımlanmış Doktora Tezi, Ankara Üniversitesi.

Şişman, M. (2002). Eğitimde Mükemmellik Arayışı. Ankara: Pegem A Yayıncılık.

Şişman, M. ve Turan, S. (2001). Eğitimde Toplam Kalite Yönetimi. Pegem A Yayıncılık, Ankara.

Tabancalı, E. ve Çakıroğlu, Z. K. (2017). Okul Müdürlerinin Etik Liderlik Davranışları İle Öğretmenlerin Örgütsel Vatandaşlık Davranışları Arasındaki İlişki. Eğitim Fakültesi Dergisi, Mersin Üniversitesi 13(1): 392-417.

Tamer, G. (2017). Etik Liderlik Yaklaşımlarının Çalışanların Örgütsel Bağhllı̆̆ına ve Performansına Etkileri: İstanbul İlinin Bahçelievler İlçesinde Özel Să̆lık Kuruluşlarında Bir Araştırma, Yayımlanmış Doktora Tezi, İstanbul Gelişim Üniversitesi.

Turhan, M. (2007). Genel Mesleki Lise Yöneticilerinin Etik Liderlik Davranışlarının Okullardaki Sosyal Adalet Üzerindeki Etkisi. Yayınlanmış Doktora Tezi, Fırat Üniversitesi.

Yardibi, N. (1991). Okul Müdürünün Yönetimsel Davranışı ve Öğretmen Bağglı̆̆ğ. Yayınlanmış Doktora Tezi, Hacettepe Üniversitesi, Sosyal Bilimler Enstitüsü, Ankara.

Yavuz. S. A. (2006). Çă̆daş Yöneticilik ve Liderlik. Yayınlanmamış Yüksek Lisans Tezi, Beykent Üniversitesi, İstanbul.

Yazıcıoğlu, İ. ve Topaloğlu, I.G. (2009). Örgütsel Adalet ve Bağlllık İlişkisi: Konaklama İşletmelerinde Bir Uygulama. İşletme Araştırmaları Dergisi, 1(1), 3-16.

Yeniçeri, Ö., Demirel, Y. ve Seçkin, Z. (2009). Örgütsel Adalet ile Duygusal Tükenmişlik Arasındaki İlişki: İmalat Sanayi Çalışanları Üzerine Bir Araştırma. Karamanoğlu Mehmetbey Üniversitesi İktisadi ve İdari Bilimler Fakültesi Dergisi, (16), 83-99.

Yıldırım, A. (2010). Etik Liderlik ve Örgütsel Adalet İlişkisi Üzerine Bir Uygulama. Yüksek Lisans Tezi, Karamanoğlu Mehmetbey Üniversitesi, Sosyal Bilimler Enstitüsü, Kamu Yönetimi Anabilim Dalı, Karaman.

Yılmaz, E. (2005). Okullarda Örgütsel Güven Ölçeği'nin Geçerlik ve Güvenirlik Çalışması, Selçuk Üniversitesi Sosyal Bilimler Enstitüsü Dergisi, Sayı:14, Konya. 
Y1lmaz, E. (2006). Okullardaki Örgütsel Güven Düzeyinin Okul Yöneticilerinin Etik Liderlik Özellikleri ve Bazı Değgişkenler Açısından İncelenmesi. Yayınlanmış Doktora Tezi, Selçuk Üniversitesi, Konya.

Zeyrek, A.O. (2008). MEB 2005 Öğretmenlik Kariyer Basamakları Yükselme Stnavında Öğretmenlerin Başarı Durumları ile Örgütsel Bağhlıkları Arasındaki İlişkinin İncelenmesi. Yayınlanmış Yüksek Lisans Tezi, Yeditepe Üniversitesi, İstanbul. 